\title{
Influence of Pancreatic Hormones on Enzymes concerned with Urea Synthesis in Rat Liver
}

\author{
By PATRICIA McLEAN AND F. NOVELLO* \\ Courtauld Institute of Biochemistry, The Middlesex Hospital Medical School, London, W. 1
}

(Received 8 May 1964)

\begin{abstract}
1. The activities of enzymes of the urea cycle [carbamoyl phosphate synthetase, ornithine transcarbamoylase, argininosuccinate synthetase, argininosuccinase (these last two comprising the arginine-synthetase system) and arginase] have been measured in control, alloxan-diabetic and glucagon-treated rats. In addition, measurements were made on alloxan-diabetic rats treated with protamine-zincinsulin. 2. Treatment of rats with glucagon for 3 days results in a marked increase in the activities of three enzymes of the urea cycle (carbamoyl phosphate synthetase, argininosuccinate synthetase and argininosuccinase). The pattern of change in the alloxan-diabetic group is very similar to that of the glucagon-treated group, although the magnitude of the change was much greater. 3. Comparison was made of the actual and potential rate of urea synthesis in normal and diabetic rats. In both groups the potential rate of urea production, as measured by the activity of the rate-limiting enzyme, argininosuccinate synthetase, slightly exceeds the actual rate of synthesis by liver slices in the presence of substrates. The relative activities of the actual and potential rates were similar in the two groups of animals, this ratio being $1: 0 \cdot 70$. 4. In the alloxan-diabetic rats treated with protamine-zinc-insulin for 2.5 or 4 days there was a marked increase in liver weight. This was associated with a rise in the total hepatic activity of the urea-cycle enzymes located in the soluble fraction of the cell (the arginine-synthetase system and arginase) after 2.5 days of treatment. After 4 days of treatment the concentration of these enzymes/g. of liver decreased, and the total hepatic content then reverted to the untreated alloxan-diabetic value. 5. No effects of glucagon or of insulin in vitro could be found on the rate of urea production by liver slices. 6. The present results are discussed in relation to how far this pattern of change is typical of conditions resulting in a high urea output, and comparison has been made with other values in the literature.
\end{abstract}

It has been known for many years that the diabetic state is associated with a greatly increased nitrogen excretion, and this and the effect of insulin in causing nitrogen retention have been widely studied (Minkowski, 1893; Atchley, Loeb, Richards, Benedict \& Driscoll, 1933; Soskin \& Levine, 1946; Chaikoff \& Forker, 1950). More recently glucagon has been shown to be a hormone closely associated with protein catabolism, increased amino acid breakdown and increased urea synthesis (Tyberghein, 1953; Salter, Davidson \& Best, 1957; Best, 1959; Miller, 1960). Thus these two hormones, secreted by the pancreas, have powerful and antagonistic effects on both carbohydrate and nitrogen metabolism (see de Duve, 1953; Lukens, 1959; Randle, 1963).

* Present address: Institute of General Pathology, University of Padua, Italy.
Though certain of the urea-cycle enzymes have been studied in alloxan-diabetic-rat liver, namely arginase (Folley \& Greenbaum, 1949) and the overall arginine-synthetase system (Freedland \& Sodikoff, 1962), there has as yet been no systematic study of the overall pattern of change of all five enzymes of this cycle. Glucagon also presents an interesting problem, particularly since the studies of Miller (1960), who showed an in vitro effect of this hormone in promoting urea synthesis by isolated perfused liver.

The systematic nomenclature and number adopted by the International Union of Biochemistry Commission on Enzymes for the five urea-cycle enzymes are as follows: carbamoyl phosphate synthetase (adenosine triphosphate-carbamate phosphotransferase, EC 2.7.2.2), ornithine transcarbamoylase (carbamoyl phosphate-L-ornithine 
carbamoyltransferase, EC 2.1.3.3), argininosuccinate synthetase [L-citrulline-L-aspartate ligase (adenosine 5'-phosphate), EC 6.3.4.5], argininosuccinase (L-argininosuccinate arginine-lyase, EC 4.3.2.1) and arginase (L-arginine ureohydrolase, EC 3.5.3.1). The influence of pancreatic hormones on the activities of these enzymes has been investigated, since the overall effect of increased urea output could be induced by an alteration in either the rate-limiting enzyme, argininosuccinate synthetase, alone, or by more widespread changes in this enzyme system. In the results described below on the effects of diabetes and glucagon treatment on the pattern of change of the activities of the urea-cycle enzymes, the most striking result that has emerged is the close parallelism of the modification produced by these two treatments. In each case the total hepatic activities of the same three enzymes, carbamoyl phosphate synthetase, argininosuccinate synthetase and argininosuccinase, were increased, whereas those of ornithine transcarbamoylase and arginase were relatively unchanged.

\section{METHODS}

Materials. Commerical reagents were used with the exception of $\alpha$-isonitrosopropiophenone, which was synthesized by the method of Claisen \& Manasse (1889), and carbamoyl phosphate, which was synthesized by the method of Spector, Jones \& Lipmann (1957). These two compounds were prepared by Miss M. W. Gurney. Argininosuccinic acid was a product of California Corp. for Biochemical Research, Los Angeles, Calif., U.S.A. Glucagon preparations were kindly given by Novo Terapeutisk Laboratorium, Copenhagen, Denmark, and by Eli Lilly Co., Indianapolis, Ind., U.S.A.

Glucagon treatment of rats. Young male rats (initial body wt. 150-160 g.) were used. Three doses of glucagon, each of $100 \mu \mathrm{g}$., were administered daily by subcutaneous injection for 2 days and the rats were killed on the third day, $1 \mathrm{hr}$. after the administration of the last $100 \mu \mathrm{g}$. dose of glucagon. Control animals received injections of $0.9 \% \mathrm{NaCl}$. Rats were pair-fed during the period of treatment. In most cases rats were kept in individual metabolism cages and the daily urea excretion was measured.

Diabetic rats. Adult male rats (initial body wt. approx. $250 \mathrm{~g}$.) were starved for $48 \mathrm{hr}$. and then alloxan monohydrate was injected subcutaneously, the dose being $19 \mathrm{mg}$. $/ 100 \mathrm{~g}$. body wt. (Kass \& Waisbren, 1945). The alloxan was dissolved in $0 \cdot 1 \mathrm{~m}$-acetate buffer, $\mathrm{pH} 4 \cdot 5$, before injection, to minimize inactivation of alloxan, according to the method of Klebanoff \& Greenbaum (1954). The alloxandiabetic rats were given 1 unit of protamine-zinc-insulin daily for the first week after administration of alloxan; this greatly increased the overall survival rate. Thereafter insulin was withdrawn and the rats were maintained on the stock diet ad lib. for 2 weeks. At this stage the diabetic rats were transferred to individual cages and were pair-fed with control rats of the same age and body weight. The period of paired feeding lasted for a further 2 weeks, and the rats were killed 5 weeks after the administration of alloxan and 4 weeks after the cessation of insulin treatment. In most cases the diabetic and control rats were kept in metabolism cages for the final 3 days of the experimental period, and the daily urea and glucose outputs were measured. The urea excreted was measured by the colorimetric method of Archibald (1945) and the glucose by the method of Nelson (1944). Diabetic rats treated with protamine-zinc-insulin were pair-fed with diabetic rats.

Urea-cycle enzymes. The activities of the urea-cycle enzymes were measured essentially according to the method of Brown \& Cohen (1959) as modified by McLean \& Gurney (1963). Liver was homogenized in $0 \cdot 1 \%$ cetyltrimethylammonium bromide solution, in the ratio $1 \mathrm{~g}$. of liver to $9.0 \mathrm{ml}$. of solution. The supernatant fraction after centrifugation at $4000 \mathrm{~g}$ for $15 \mathrm{~min}$. at $5^{\circ}$ was used for the assay of all enzymes except arginase. This latter enzyme was estimated by diluting one part of the whole homogenate prepared in $0.1 \%$ cetyltrimethylammonium bromide with 9 parts of 'manganese saline' ( $8 \mathrm{~g}$. of $\mathrm{MnSO}_{4}, 4 \mathrm{H}_{2} \mathrm{O}$ and $9 \mathrm{~g}$. of $\mathrm{NaCl} / \mathrm{l}$.) and incubating for $30 \mathrm{~min}$. at $37^{\circ}$ to activate the enzyme in accordance with the method of Folley \& Greenbaum (1948). The enzyme activities were measured as described by McLean \& Gurney (1963) with one exception, that of carbamoyl phosphate synthetase.

Carbamoyl phosphate synthetase. It was observed that liver homogenates prepared from alloxan-diabetic rats gave very high enzymic blank values for urea content in the absence of added substrate. Thus $0.1 \mathrm{ml}$. of supernatant fraction, prepared as described above, sometimes contained up to $15 \mu \mathrm{g}$. of urea as estimated by the sensitive colorimetric method with $\alpha$-isonitrosopropiophenone described by Archibald (1945). This high value could be allowed for in the assay of all the enzymes involving the final determination of the urea content of the incubation mixture by setting up suitable blank values. When citrulline was the end product measured the problem presented greater difficulties, owing to the interaction of urea and citrulline in the diacetylmonoxime reaction of Archibald (1944). The correction for this interference, which is of considerable importance in the assay of carbamoyl phosphate-synthetase activity, is fully discussed in the Addendum (McLean, Novello \& Gurney, 1965). In essence, this correction is necessary because it was found that when urea and citrulline were present together

\section{Table 1. Interaction of citrulline and urea in the diacetylmonoxime colour reaction}

The difference in $E_{490 \mathrm{~m} \mu}$ due to citrulline is that obtained in the presence of urea minus the colour due to urea alone. This was expressed as a percentage of the colour with citrulline alone and this is shown in the last column as percentage potentiation of colour. The colour reaction of Archibald (1944) was used: the time of heating was $15 \mathrm{~min}$. and the colour read $10 \mathrm{~min}$. later.

\begin{tabular}{|c|c|c|c|c|}
\hline $\begin{array}{l}\text { Citrulline } \\
\quad(\mu \mathrm{g} .)\end{array}$ & $\begin{array}{l}\text { Urea } \\
(\mu \mathrm{g} .)\end{array}$ & $E_{490 \mathrm{~m} \mu}$ & $\begin{array}{c}\text { Difference in } \\
E_{490 \mathrm{~m} \mu} \text { due } \\
\text { to citrulline }\end{array}$ & $\begin{array}{c}\text { Percentage } \\
\text { potentiation } \\
\text { of colour }\end{array}$ \\
\hline 30 & 0 & $0 \cdot 233$ & - & - \\
\hline 60 & 0 & 0.576 & - & - \\
\hline 90 & 0 & $1 \cdot 042$ & - & - \\
\hline 0 & 30 & $0 \cdot 252$ & - & - \\
\hline 30 & 30 & 0.658 & 0.406 & 174 \\
\hline 60 & 30 & 1.068 & $0 \cdot 816$ & 142 \\
\hline 90 & 30 & $1 \cdot 588$ & $1 \cdot 336$ & 128 \\
\hline
\end{tabular}


the resultant colour was greater than the sum of the two compounds measured independently, i.e. that urea had a potentiating effect. Citrulline calibration curves were constructed with different amounts of urea present (amounts greater than $15 \mu \mathrm{g}$. of urea/assay caused little further potentiation of colour) and the correction factor required was calculated from these curves (see McLean et al. 1965). If the $E_{490 \mathrm{~m} \mu}^{1 \mathrm{~cm}}$ values for 30,60 and $90 \mu \mathrm{g}$. of citrulline are taken to be $100 \%$, then the potentiating effect of $30 \mu \mathrm{g}$. of urea was found to be 174,142 and $128 \%$ of the original values respectively (see Table 1). The greatest effect is at the lowest concentration of citrulline, and these percentage changes illustrate the importance of this correction factor.

Ornithine transcarbamoylase. The activity of this enzyme in liver is normally so great that only $0.01 \mathrm{ml}$. of supernatant fraction, prepared as described above, is added to $2 \cdot 0 \mathrm{ml}$. of reaction mixture. The amount of urea added is, therefore, negligible, and the above corrected calibration curve need only be applied to the carbamoyl phosphate-synthetase system.

Enzyme units. The enzyme activities were all expressed in terms of a unit, defined as the amount of enzyme catalysing the formation of $1 \mu$ mole of urea or citrulline $/ \mathrm{hr}$. at $37^{\circ}$ under the conditions of the assay.

Urea synthesis by liver slices. Comparison was made of the rate-limiting enzyme of the urea cycle, argininosuccinate

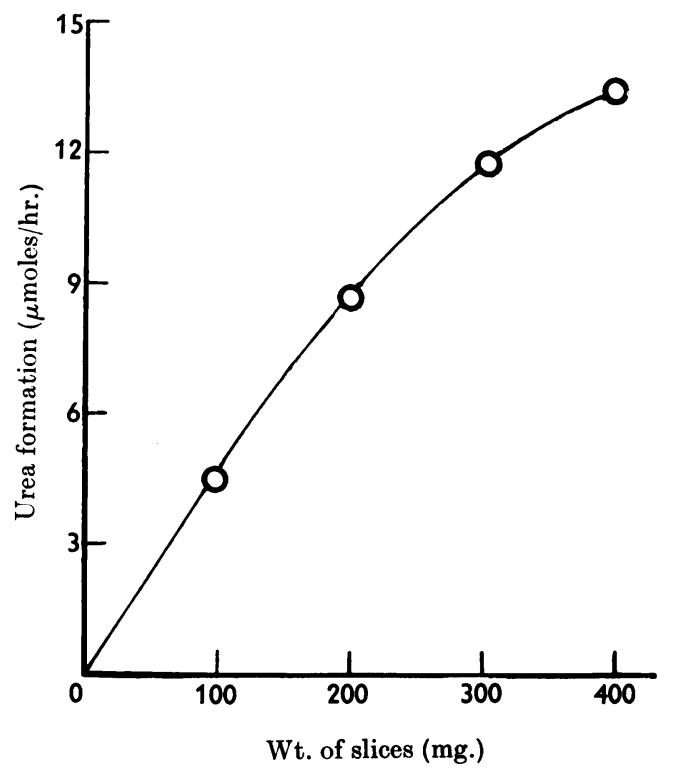

Fig. 1. Proportionality between rate of urea synthesis and weight of liver slices used. The medium contained 100 $\mu$ moles of $\mathrm{NH}_{4} \mathrm{Cl}, 10 \mu$ moles of ornithine, $5 \cdot 0 \mathrm{ml}$. of KrebsRinger bicarbonate medium and $100-400 \mathrm{mg}$. of liver slices. The gas phase was $\mathrm{O}_{2}+\mathrm{CO}_{2}(95: 5)$, and the total volume of the reaction mixture was $5.5 \mathrm{ml}$. The time of incubation was $1 \mathrm{hr}$. Results are given as $\mu$ moles of urea synthesized/hr. Urea was estimated by the colorimetric method described by Archibald (1944). Further details are given in the Methods section. synthetase, with the actual rate of urea synthesis by liver slices. The conditions used in the present experiments are based on those described by Krebs \& Henseleit (1932), Krebs (1952) and Dickens \& Weil-Malherbe (1943). The final assay medium adopted included : $100 \mu$ moles of $\mathrm{NH}_{4} \mathrm{Cl} ; 10 \mu$ moles of ornithine; $5.0 \mathrm{ml}$. of Krebs-Ringer bicarbonate medium (Umbreit, Burris \& Stauffer, 1949); $200 \mathrm{mg}$. of rat-liver slices. The gas phase was $\mathrm{O}_{2}+\mathrm{CO}_{2}(95: 5)$, and the total volume of the reaction mixture was $5.5 \mathrm{ml}$. The tissue slices were incubated at $37^{\circ}$ for $1 \mathrm{hr}$. at the end of which period the flasks were removed from the bath and the reaction was stopped by the addition of $0.5 \mathrm{ml}$. of $10 \mathrm{~N}$-perchloric acid. The urea content was determined, with $1.0 \mathrm{ml}$. samples of the supernatant fraction after removal of the precipitated proteins by centrifugation, by means of the colorimetric method with $\alpha$-isonitrosopropiophenone described by Archibald (1945).

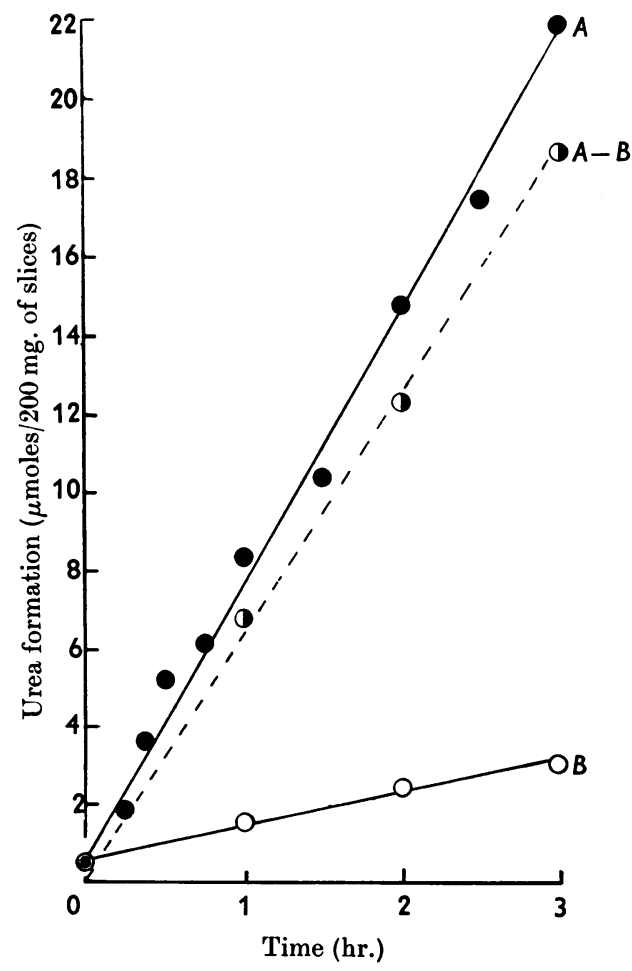

Fig. 2. Proportionality between rate of urea synthesis and time of incubation. The medium contained $100 \mu$ moles of $\mathrm{NH}_{4} \mathrm{Cl}, 10 \mu$ moles of ornithine, $5.0 \mathrm{ml}$. of $\mathrm{Krebs}-$ Ringer bicarbonate medium and $200 \mathrm{mg}$. of liver slices. The gas phase was $\mathrm{O}_{2}+\mathrm{CO}_{2}(95: 5)$, and the total volume of the reaction mixture was $5.5 \mathrm{ml}$. The time of incubation ranged from $15 \mathrm{~min}$. to $3 \mathrm{hr}$. The urea production (๑) represents the complete system $(A)$. The urea production by $200 \mathrm{mg}$. of liver slices incubated in Krebs-Ringer bicarbonate medium without added substrate $(O)$ represents the blank value from endogenous substrates $(B)$. The rate of urea formation corrected for this blank value $(O)$ is shown by the broken line $(A-B)$. 
Preliminary experiments were undertaken to establish that, in the present experiments, the rate of urea synthesis by liver slices was proportional to the weight of tissue used (Fig. 1) and the time of incubation (Fig. 2). These results show that the rate of urea production ( $\mu$ moles $/ \mathrm{hr}$.) is almost directly proportional to the weight of the liver slices up to $300 \mathrm{mg}$. of tissue, and in succeeding experiments $200 \mathrm{mg}$. of liver slices was used. The rate of urea production by $200 \mathrm{mg}$. of liver slices is directly proportional to the time of incubation for at least $3 \mathrm{hr}$. There is a small blank value of urea production from endogenous substrates; this is also linear over this time period (Fig. 2). The effect of changes in substrate concentration are shown in Figs. 3 and 4 . In Fig. 3 the relative amounts of the substrates were maintained in a constant proportion to one another as described in the basic assay system, and the amounts of this substrate mixture added to each flask were then varied from one-tenth to twice the amounts normally present: very high substrate concentrations have an inhibitory effect on urea synthesis by liver slices.

The effect of variations in each substrate in turn, the remaining components being kept at the concentration described in the basic assay mixture, is shown in Fig. 4. The substitution of alanine for $\mathrm{NH}_{4} \mathrm{Cl}$ as a source of amino groups for urea formation led to a very low rate of urea formation (Fig. 4).

The addition of aspartic acid had little effect on urea synthesis by slices, and no consistent difference could be

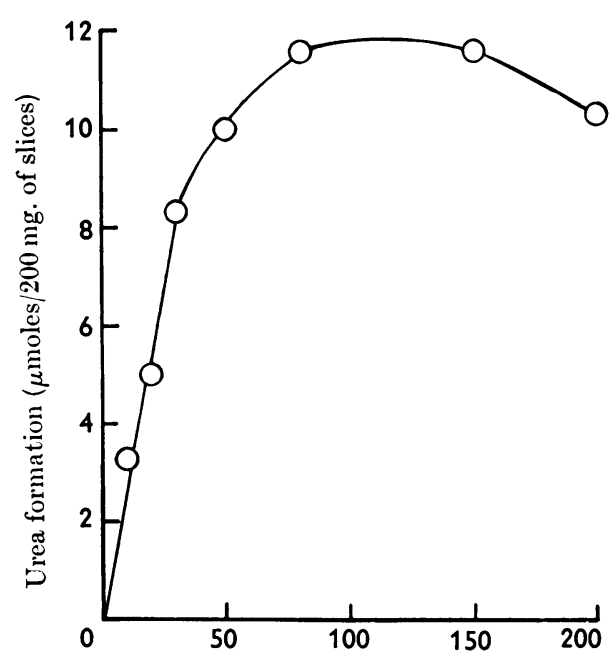

Amounts of substrates ( $\%$ of those in basic assay)

Fig. 3. Effect of substrate concentration on the rate of urea production by liver slices. The relative amounts of the substrates were maintained in a constant proportion one to another as described in the basic assay system (100 $\mu$ moles of $\mathrm{NH}_{4} \mathrm{Cl}$ and $10 \mu$ moles of ornithine), and the amounts of substrate added to each flask varied from one-tenth to twice this amount. The basic assay mixture is represented as $100 \%$. Each flask contained $200 \mathrm{mg}$. of liver slices and $5.0 \mathrm{ml}$. of Krebs-Ringer bicarbonate medium. The gas phase was $\mathrm{O}_{2}+\mathrm{CO}_{2}(95: 5)$. The time of incubation was $1 \mathrm{hr}$., and the temperature $37^{\circ}$. found when $N$-acetylglutamic acid, the cofactor required for carbamoyl phosphate synthetase, was added to the medium. The lack of effect in these cases could be due to their rate of penetration into the liver slices (see Ratner, 1954). The addition of glucose to the medium in which liver slices were incubated did not increase urea formation. This was tested since the amount of endogenous glucose and glycogen in the liver could be very different in control, diabetic and glucagon-treated rats, and the negative results are in keeping with the work of Krebs \& Henseleit (1932), who found that glucose caused no stimulation in urea production whereas pyruvate, lactate or fructose all caused a marked increase in the rate of urea synthesis by liver slices.

Dickens \& Weil-Malherbe (1943) in their studies on urea synthesis by primary hepatomas and liver also fortified the medium with added lactate. In the present experiment no such additional compound was used since such profound changes occur in carbohydrate metabolism of diabetic rats that it seemed possible that the presence of fructose, pyruvate or lactate would add further difficulty to the interpretation of the results on urea production by liver slices. Moreover, preliminary experiments with liver slices from control rats indicated that fructose, glucose, lactate or pyruvate did not cause any marked stimulation of urea synthesis. Unwashed liver slices were used in the present experiments, in contrast with the work of Krebs \& Henseleit (1932), and the endogenous substrate present is probably sufficient to maintain an adequate supply of energy for urea synthesis. The rate of urea synthesis found in these present

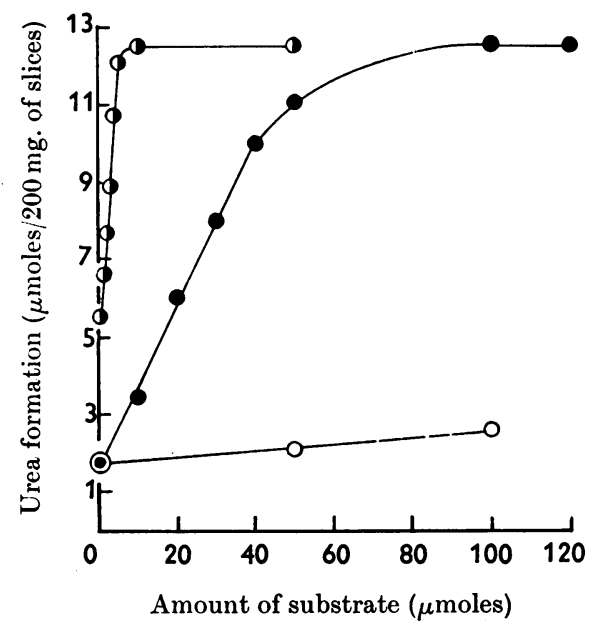

Fig. 4. Effects of ornithine, ammonia and alanine concentrations on the rate of formation of urea by liver slices. Liver slices (200 mg.) were incubated with $5.0 \mathrm{ml}$. of KrebsRinger bicarbonate medium with the following substrates: - Ornithine, varied from 0 to $50 \mu$ moles; $\mathrm{NH}_{4} \mathrm{Cl}$ at fixed concentration of $100 \mu$ moles. $-\mathrm{NH}_{4} \mathrm{Cl}$, varied from 0 to $120 \mu$ moles; ornithine at fixed concentration of $10 \mu$ moles. $\bigcirc$, Alanine, varied from 0 to $100 \mu$ moles; ornithine at fixed concentration of $10 \mu$ moles; no $\mathrm{NH}_{4} \mathrm{Cl}$. The final volume was $5.5 \mathrm{ml}$. in all cases. The gas phase was $\mathrm{O}_{2}+\mathrm{CO}_{2}(95: 5)$. Results are shown as $\mu$ moles of urea formed $/ 200 \mathrm{mg}$. of slices/hr. 
experiments with the addition of $\mathrm{NH}_{4} \mathrm{Cl}$ and ornithine corresponds well with the values quoted by Krebs \& Henseleit (1932) and is only a little lower than those of Dickens \& Weil-Malherbe (1943), who also added lactate to the medium.

Determination of nucleic acids. The extraction procedure adopted was that of Schneider (1946). DNA was estimated by a modification of the diphenylamine method of Dische (1930) described by Burton (1956). RNA was determined by the orcinol method of Mejbaum (1939), the time of heating being increased to $45 \mathrm{~min}$.

Determination of protein. The protein content of whole homogenates was estimated by the colorimetric method of Lowry, Rosebrough, Farr \& Randall (1951).

Statistical treatment of results. Fisher's $t$ test was used, a difference between two mean values being regarded as significant if $\boldsymbol{P}$ was no greater than $0 \cdot 05$. Values of $\boldsymbol{P}$ greater than 0.1 are quoted in the Tables as N.S. (not significant).

\section{RESULTS}

Treatment of rats with glucagon for 3 days results in a marked increase in the activity of three of the enzymes of the urea cycle, carbamoyl phosphate synthetase, argininosuccinate synthetase and argininosuccinase, the last two comprising the argininesynthetase system (see Table 2 and Fig. 5). The pattern of change in the alloxan-diabetic group of rats is very similar to that of the glucagon-treated

\section{Table 2. Effect of glucagon treatment on the activities of the urea-cycle enzymes in rat liver}

Results are expressed as means \pm s.e.M. A unit of enzyme activity is defined as the amount catalysing the formation of $1 \mu$ mole of urea or citrulline/ $\mathrm{hr}$. under the conditions of assay. Fisher's $P$ values are given and are regarded as significant if $P$ is less than 0.05 ; values of $P$ greater than 0.1 are quoted as not significant (N.S.). The rats treated with glucagon for 3 days received three daily doses of Novo Terapeutisk glucagon (100 $\mu$ g./dose) subcutaneously for 3 days. The protein contents, in $\mathrm{mg} . / 10 \mathrm{ml}$. of cetyltrimethylammonium bromide extract (equivalent to $1 \mathrm{~g}$. of liver), were $109 \pm 7$ and $96 \pm 9$ for control and glucagon-treated rats respectively. The group treated for $2 \mathrm{hr}$. received a single injection of glucagon $\left(200 \mu \mathrm{g}_{\circ}\right)$ and the controls were injected with $0.9 \% \mathrm{NaCl}$. In this group urea synthesis by $200 \mathrm{mg}$. of liver slices, incubated with $10 \mu$ moles of ornithine and $100 \mu$ moles of $\mathrm{NH}_{4} \mathrm{Cl}$ with $5 \mathrm{ml}$. of Krebs-Ringer bicarbonate medium, gas phase $\mathrm{O}_{2}+\mathrm{CO}_{2}(95: 5)$, was determined as described in the Methods section.

Glucagon treatment: 3 days

Initial body wt. (g.)

Final body wt. (g.)

Liver wt (g.)

Carbamoyl phosphate synthetase (units/g. of liver) (total units/100 g. body wt.)

Ornithine transcarbamoylase (units/g. of liver) (total units/100 g. body wt.)

Arginine-synthetase system (units/g. of liver)

(total units/100 g. body wt.)

Argininosuccinase (units/g. of liver) (total units/100 g. body wt.)

Arginase (units/g. of liver) (total units $/ 100 \mathrm{~g}$. body wt.)

Glucagon treatment: $2 \mathrm{hr}$.

Carbamoyl phosphate synthetase (units/g. of liver) (total units/100 g. body wt.)

Arginine-synthetase system (units/g. of liver) (total units $/ 100 \mathrm{~g}$. body wt.)

Argininosuccinase (units/g. of liver) (total units/100 g. body wt.)

Urea synthesis by liver slices ( $\mu$ moles/g./hr.) ( $\mu$ moles/total liver)

\section{No. of} animals

11

3
Glucagon-treated

Control group

$154 \pm 4$
$155 \pm 4$
$7 \cdot 82 \pm 0 \cdot 31$

$233 \pm 13$

$1100 \pm 57$

$10780 \pm 830$

$58800 \pm 3670$

$84 \pm 6$

$392 \pm 37$

$168 \pm 4$

$885 \pm 41$

$111300 \pm 9650$

$549500 \pm 39900$

$650600 \pm 45700$

$259 \pm 11$

$2116 \pm 181$

N.S.

$2258 \pm 255$

$73 \pm 7$

$471 \pm 85$

$149 \pm 38$

$1116 \pm 371$

50

335
$8200+12800$

$P$

$$
\begin{gathered}
156 \pm 3 \\
147 \pm 4 \\
7 \cdot 74 \pm 0 \cdot 32
\end{gathered}
$$

$$
\begin{array}{r}
306 \pm 17 \\
1480 \pm 69
\end{array}
$$

$0 \cdot 004$

0.001

$9680 \pm 790$

N.S.

N.S.

$\begin{array}{ll}121 \pm 5 & <0.001 \\ 611 \pm 28 & <0.001\end{array}$

$284 \pm 12$
$1530 \pm 124$

$<0.001$

$<0.001$

N.S.

N.S.

$\begin{array}{cc}72 \pm 7 & \text { N.S. } \\ 528 \pm 74 & \text { N.S. } \\ 146 \pm 15 & \text { N.S. } \\ 1215 \pm 195 & \text { N.S. }\end{array}$

51

391 


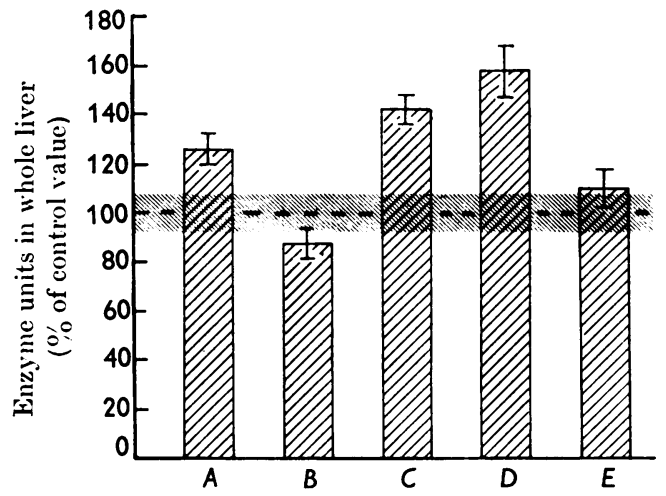

Fig. 5. Effect of glucagon treatment on the activities of urea-cycle enzymes in rat liver. Results, as enzyme units in the whole liver, are expressed as percentages of the activity in the corresponding pair-fed control groups. Vertical lines represent twice the s.E.M. The horizontal broken line is the arbitarily fixed control value of $100 \%$, the shaded area on either side of this broken line representing twice the S.E.M. for the control group. The rats were treated with glucagon for 3 days, receiving each day three doses of Novo Terapeutisk glucagon (100 $\mu \mathrm{g}$./dose) subcutaneously. Each group contains seven or more animals. $A$, Carbamoyl phosphate synthetase; $B$, ornithine transcarbamoylase; $C$, arginine-synthetase system; $D$, argininosuccinase; $E$, arginase. group: although the magnitude of the change is much greater (see Table 3 and Fig. 6), the activities of the same three enzymes are very strikingly increased. The great similarity in these two conditions with respect to the activities of enzymes of the urea cycle is most clearly shown in Figs. 5 and 6 , which illustrate the changes in the total hepatic content of these enzymes compared with pair-fed control animals. These results cannot be attributed to adaptive changes due to differences in protein intake since paired-feeding techniques were used throughout. The present pattern of change is somewhat different from those found in other treatments that cause an increased urea output (Schimke, $1962 a, b, 1963$; McLean \& Gurney, 1963).

In view of the known effects of glucagon in increasing urea production when added to a liver perfusion system (Miller, 1960), attempts were made to show short-term effects of this hormone in vivo or in vitro on urea-cycle enzymes and on urea synthesis by liver slices. Certain of these results are shown in Table 2. Particular interest centred on the three enzymes increased in the 3-day treatment period, and these were measured in these short-term experiments in an attempt to show which enzyme responded most rapidly to the hormonal treatment. Rats were killed $2 \mathrm{hr}$. after

Table 3. Effect of diabetes on the activities of the urea-cycle enzymes in rat liver

Results are expressed as means \pm s.E.M. A unit of enzyme activity is defined as the amount catalysing the formation of $1 \mu$ mole of citrulline or urea $/ \mathrm{hr}$. under the conditions of the assay. Fisher's $P$ values are given for the comparison of the control and diabetic groups; values of $P$ greater than $0 \cdot 1$ are quoted as not significant (N.S.).

\begin{tabular}{|c|c|c|c|c|c|}
\hline & Control group & Diabetic group & $\begin{array}{c}P \\
\text { (control- } \\
\text { diabetic) }\end{array}$ & $\begin{array}{l}\text { Diabetic (in coma) } \\
\text { group }\end{array}$ & $\begin{array}{l}\text { (control- } \\
\text { diabetic } \\
\text { in coma) }\end{array}$ \\
\hline No. of animals & 11 & 11 & & 4 & \\
\hline Initial body wt. (g.) & $250 \pm 6$ & $252 \pm 7$ & & $250 \pm 5$ & \\
\hline Final body wt. (g.) & $300 \pm 9$ & $225 \pm 16$ & & $156 \pm 17$ & \\
\hline Liver wt. (g.) & $11 \cdot 90 \pm 0.36$ & $10 \cdot 40 \pm 0 \cdot 84$ & & $6 \cdot 69 \pm 1 \cdot 02$ & \\
\hline Glucose excretion (g./day) & - & $9 \cdot 1 \pm 1 \cdot 6$ & & $5 \cdot 2 \pm 1 \cdot 2^{*}$ & \\
\hline Urea excretion ( $\mu$ moles/day) & $13850 \pm 1310$ & $23600 \pm 1800$ & & $10200 \pm 2200^{*}$ & \\
\hline Carbamoyl phosphate synthetase & & & & & \\
\hline $\begin{array}{l}\text { (units/g. of liver) } \\
\text { (total units/100 g. body wt.) }\end{array}$ & $\begin{array}{c}349 \pm 29 \\
1370 \pm 110\end{array}$ & $\begin{array}{c}627 \pm 54 \\
3053 \pm 390\end{array}$ & $\begin{array}{l}<0.001 \\
<0.001\end{array}$ & $\begin{array}{r}360 \pm 131 \\
1500 \pm 524\end{array}$ & $\begin{array}{l}\text { N.S. } \\
\text { N.S. }\end{array}$ \\
\hline Ornithine transcarbamoylase & & & & & \\
\hline $\begin{array}{l}\text { (units/g. of liver) } \\
\text { (total units/100 g. body wt.) }\end{array}$ & $\begin{array}{l}17000 \pm 1400 \\
67900 \pm 6140\end{array}$ & $\begin{array}{c}20900 \pm 1950 \\
100800 \pm 13800\end{array}$ & $\begin{array}{l}0 \cdot 100 \\
0 \cdot 010\end{array}$ & $\begin{array}{l}21500 \pm 1900 \\
90600 \pm 7700\end{array}$ & $\begin{array}{l}\text { N.S. } \\
0.073\end{array}$ \\
\hline Arginine-synthetase system & & & & & \\
\hline $\begin{array}{l}\text { (units/g. of liver) } \\
\text { (total units/100 g. body wt.) }\end{array}$ & $\begin{array}{c}77 \pm 6 \\
302 \pm 24\end{array}$ & $\begin{array}{l}149 \pm 16 \\
723 \pm 89\end{array}$ & $\begin{array}{l}<0.001 \\
<0.001\end{array}$ & $\begin{array}{r}96 \pm 10 \\
408 \pm 49\end{array}$ & $\begin{array}{l}0.080 \\
0.048\end{array}$ \\
\hline Argininosuccinase & & & & & \\
\hline $\begin{array}{l}\text { (units/g. of liver) } \\
\text { (total units/100 g. body wt.) }\end{array}$ & $\begin{array}{l}185 \pm 9 \\
720 \pm 32\end{array}$ & $\begin{array}{c}436 \pm 29 \\
2110 \pm 216\end{array}$ & $\begin{array}{l}<0.001 \\
<0.001\end{array}$ & $\begin{array}{c}460 \pm 36 \\
1930 \pm 106\end{array}$ & $\begin{array}{l}<0.001 \\
<0.001\end{array}$ \\
\hline $\begin{array}{l}\text { Arginase } \\
\quad \text { (units/g. of liver) } \\
\quad \text { (total units/100 g. body wt.) }\end{array}$ & $\begin{array}{l}148000 \pm 10300 \\
591000 \pm 42200\end{array}$ & $\begin{array}{l}201000 \pm 10400 \\
962000 \pm 79000\end{array}$ & $\begin{array}{r}0.004 \\
<0.001\end{array}$ & $\begin{array}{l}148800 \pm 23500 \\
618300 \pm 82700\end{array}$ & $\begin{array}{l}\text { N.S. } \\
\text { N.S. }\end{array}$ \\
\hline
\end{tabular}

* These values are the mean values for glucose and urea excretion in this group during the last $24 \mathrm{hr}$. before killing the rats for estimation of the enzyme activities. Initially this group excreted approximately the same amount of glucose and urea as the diabetic group. 
the intraperitoneal administration of a $200 \mu \mathrm{g}$. dose of glucagon: neither the activities of the enzymes nor the synthesis of urea by liver slices was altered. The addition of $200 \mu \mathrm{g}$. of glucagon (from Novo Terapeutisk or Eli Lilly Co.) to $200 \mathrm{mg}$. of liver slices incubated in vitro with $10 \mu$ moles of ornithine and $100 \mu$ moles of ammonium chloride

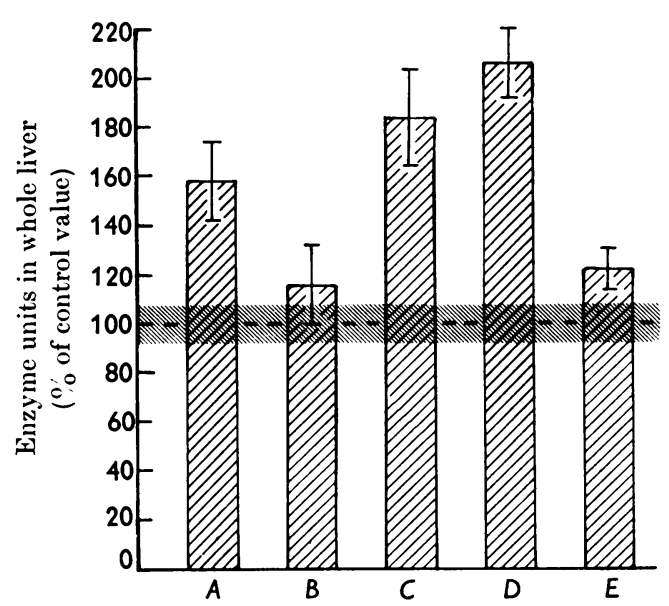

Fig. 6. Activities of urea-cycle enzymes in alloxan-diabetic and control rats. Results, as enzyme units in the whole liver, are expressed as percentages of the activity in the corresponding pair-fed control groups. Vertical lines represent twice the S.E.M. The horizontal broken line is the arbitrarily fixed control value of $100 \%$, the shaded area on either side of this broken line representing twice the S.E.M. for the control group. Each group contains 11 rats. $A$, Carbamoyl phosphate synthetase; $B$, ornithine transcarbamoylase; $C$, arginine-synthetase system; $D$, argininosuccinase; $E$, arginase. also failed to increase urea production during a $2 \mathrm{hr}$. incubation period: average values from five separate experiments are $52 \cdot 4 \pm 2 \cdot 6$ and $51 \cdot 3 \pm 1 \cdot 6 \mu$ moles of urea synthesized by liver slices from normal rats incubated in the presence and absence of glucagon respectively. In one experiment glucagon was added in separate $100 \mu \mathrm{g}$. portions at each hour and the total incubation period was extended to $3 \mathrm{hr}$.: this treatment also failed to elicit any response, as did the addition of gelatin together with glucagon.

There are in the literature several cases of disagreement among workers from various Laboratories on the effect of diabetes on certain enzymes and coenzymes; several such examples have been selected in the review by de Duve \& Hers (1957, see p. 170). Table 3 shows that the condition of the diabetic rat had a very marked effect on the activities of the urea-cycle enzymes. Most of the rats had blood sugar values of $500-600 \mathrm{mg}$. $100 \mathrm{ml}$. of blood, and were excreting up to $10 \mathrm{~g}$. of glucose/day. Certain rats after 2-3 weeks in such a condition suddenly became weak, the blood sugar values rose to even higher values (over $700 \mathrm{mg}$. $100 \mathrm{ml}$. of blood), the urine volume, urea excretion and glucose excretion fell in relation to the previously recorded values, and the animals went into coma. The activities of the urea-cycle enzymes in such animals were markedly different from those of the main diabetic group and approximated more closely to those of control animals, most of the enzymes of the urea cycle being within the range of the control group both expressed as units/g. of liver and total units $/ 100 \mathrm{~g}$. body wt., the exception being argininosuccinase. The activity of this last-named enzyme was still significantly higher in the diabetic group in coma than in the control group and was not significantly different from that of the main diabetic

Table 4. Actual and potential rates of urea synthesis in normal and diabetic rats

Results are expressed as means \pm S.E.M. The urea excretion $/ \mathrm{hr}$. is calculated from the $24 \mathrm{hr}$. output. Liver slices (200 mg.) were incubated for $1 \mathrm{hr}$. in $5.0 \mathrm{ml}$. of Krebs-Ringer bicarbonate medium containing $100 \mu \mathrm{moles}$ of $\mathrm{NH}_{4} \mathrm{Cl}$ and $10 \mu$ moles of ornithine. The gas phase was $\mathrm{O}_{2}+\mathrm{CO}_{2}(95: 5)$. The urea initially present in the liver slices was determined separately and subtracted from the value obtained after incubation of liver slices for $1 \mathrm{hr}$. in the presence of substrates. The initial values were $5 \cdot 5 \pm 0.74$ and $12 \cdot 5 \pm 0 \cdot 71 \mu$ moles of urea/g. for liver slices from control and diabetic rats respectively. The activity of the rate-limiting arginine-synthetase system was determined as described in the Methods section.

No. of animals

Body wt. (g.)

Liver wt. (g.)

Blood sugar (mg./100 ml.)

Urea excretion ( $\mu$ moles/hr.)

Urea synthesized by liver slices ( $\mu$ moles/g./hr.)

( $\mu$ moles/whole liver/hr.)

Arginine-synthetase system

( $\mu$ moles/g./hr.)

( $\mu$ moles/whole liver/hr.)

$\begin{array}{cc}\text { Control group } & \text { Diabetic group } \\ 6 & 6 \\ 218 \pm 16 & 205 \pm 9 \\ 9 \cdot 09 \pm 0 \cdot 63 & 9 \cdot 75 \pm 0 \cdot 32 \\ 97 \pm 6 & 547 \pm 45 \\ 446 \pm 44 & 921 \pm 69\end{array}$

$\begin{array}{ccc}68 \pm 7 & 96 \pm 4 & 0 \cdot 002 \\ 625 \pm 93 & 928 \pm 33 & 0 \cdot 012 \\ & & \\ 96 \pm 10 & 137 \pm 9 & 0 \cdot 013 \\ 860 \pm 104 & 1340 \pm 106 & 0 \cdot 014\end{array}$


Table 5. Activities of the urea-cycle enzymes in liver from normal and insulin-treated rats

Results are expressed as means \pm s.E.M. A unit of enzyme activity is defined as the amount catalysing the formation of $1 \mu$ mole of urea or citrulline/hr. under the conditions of the assay. Fisher's $P$ values are given and are regarded as significant if $P$ is less than 0.05 ; values of $P$ greater than 0.1 are quoted as not significant (N.S.). The insulin-treated rats received two daily subcutaneous injections, each of 2 units of protamine-zinc-insulin, for 5 days; controls were injected with $0.9 \% \mathrm{NaCl}$.

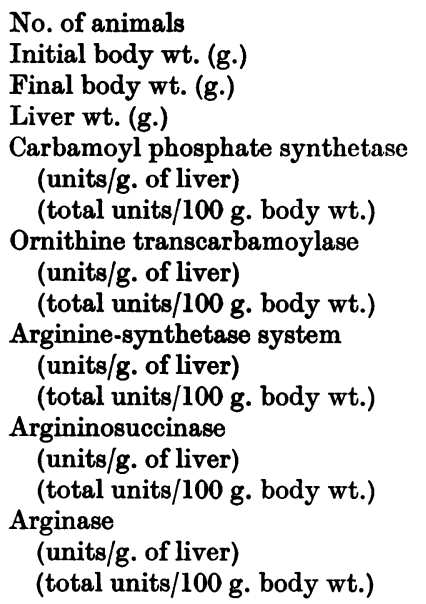

$\begin{array}{ccc} & \text { Insulin-treated } & \\ \text { Control group } & \text { group } & P \\ 9 & 5 & \\ 250 \pm 6 & 245 \pm 7 & \\ 309 \pm 8 & 255 \pm 8 & \\ 11 \cdot 76 \pm 0 \cdot 35 & 10 \cdot 88 \pm 0 \cdot 50 & \\ & & \text { N.S. } \\ 348 \pm 27 & 314 \pm 58 & \text { N.S. } \\ 1394 \pm 104 & 1287 \pm 230 & \text { N.S. } \\ & & \text { N.S. } \\ 15900 \pm 1320 & 14900 \pm 960 & \text { N.S. } \\ 60000 \pm 4560 & 63120 \pm 2440 & \text { N.S. } \\ 72 \pm 5 & & \\ 271 \pm 14 & 306 \pm 36 & \text { N.S. } \\ 185 \pm 11 & 175 \pm 10 & \text { N.S. } \\ 700 \pm 30 & 749 \pm 52 & \text { N.S. } \\ 143000 \pm 11700 & 177400 \pm 19100 & \text { 0.031 }\end{array}$

\section{Table 6. Activities of the urea-cycle enzymes in liver from alloxan-diabetic rats and alloxan-diabetic rats treated with insulin}

Results are expressed as means \pm s.e.m. A unit of enzyme activity is defined as the amount catalysing the formation of $1 \mu \mathrm{mole}$ of urea or citrulline/hr. under the conditions of the assay. Fisher's $P$ values are given for the comparison of the diabetic rats treated with insulin with the diabetic group, and are regarded as significant if $P$ is less than 0.05 ; values of $P$ greater than 0.1 are quoted as not significant (N.S.). The insulin-treated rats received daily subcutaneous injections, each of 2 units of protamine-zinc-insulin, and a final injection of crystalline insulin ( 2 units) $1 \mathrm{hr}$. before being killed for estimation of the enzyme activities.

$\begin{array}{llll}\text { Diabetic group } 2 & P & \text { Diabetic group } 3 & P\end{array}$ treated with insulin (group 1- treated with insulin (group 1-

No. of animals

Final body wt. (g.)

Liver wt. (g.)

Liver composition

Protein (mg./g. of liver)

DNA P (mg./100 g. of liver)

RNA P (mg./100 g. of liver)

Carbamoyl phosphate synthetase (units/g. of liver)

(total units/100 g. body wt.)

Ornithine transcarbamoylase (units/g. of liver) (total units/100 g. body wt.)

Arginine-synthetase system (units/g. of liver)

(total units/100 g. body wt.)

Argininosuccinase (units/g. of liver) (total units/100 g. body wt.)

Arginase (units/g. of liver) (total units/100 g. body wt.) 14
Diabetic group 1

6
$175 \pm 6$
$7 \cdot 54 \pm 0 \cdot 31$

$206 \pm 9$

$25 \pm 1 \cdot 5$

$66 \pm 4$

$760 \pm 53$
$3250 \pm 765$

$24700 \pm 2315$

$105000 \pm 7570$

$$
159 \pm 9
$$

$685 \pm 55$

$409 \pm 11$

$1766 \pm 140$

$166400 \pm 9540$ $720000 \pm 75960$ for $2 \cdot 5$ days

(group 1-
group 2)

6

$223 \pm 19$

$15 \cdot 44 \pm 0 \cdot 54$

$<0.001$

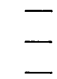

$598 \pm 82$

$4210 \pm 620$

$21080 \pm 4100$

$155000 \pm 53000$

$170 \pm 9$

$1240 \pm 184$

$452 \pm 14$

$3237 \pm 322$

$186400 \pm 13000$

$1308000 \pm 120000$

N.S

N.S.

N.S.

N.S.

0.020

$0 \cdot 034$

0.003 for 4 days

group 3)

6

$239 \pm 19$

$15.55 \pm 1.24<0.001$

$185 \pm 12$

$19 \pm 1 \cdot 2$

$61 \pm 7$

N.S.

0.038

N.S.

$358 \pm 31$

$3880 \pm 667$

$<0.001$

$15300 \pm 1530$

N.S. $\quad 97600 \pm 3600 \quad$ N.S.

0.009

$119 \pm 10$

$784 \pm 100$

$0 \cdot 016$

N.S.

$296 \pm 26$

$1970 \pm 269$

0.004

N.S. $\quad 137000 \pm 13500 \quad$ N.S.

N.S. $0.005909000 \pm 143000 \quad$ N.S.

Bioch. 1965, 94 
group. When the total hepatic content of these enzymes is considered the activities of both carbamoyl phosphate synthetase and argininosuccinate synthetase tend to be lower than the control values: carbamoyl phosphate-synthetase activity is $2355 \pm 760$ and $4150 \pm 390$ for the diabetic rats in coma and control group respectively; the corresponding values for argininosuccinate synthetase are $650 \pm 140$ and $915 \pm 68$.

Comparison has been made of the actual and potential rates of urea synthesis in normal and diabetic rats (Table 4). In both groups of rats the potential rate of urea production, as measured by the activity of the rate-limiting arginine-synthetase system, exceeds the actual rate of synthesis by the tissue slices in the presence of substrate; their relative activities were closely similar in the two groups of rats, the ratios being $1: 0 \cdot 71$ in the control group and 1:0.70 in the diabetic group.

The effects of insulin treatment on the activities of the urea-cycle enzymes in normal and diabetic rats are given in Tables 5 and 6 . Treatment with insulin has little or no effect on the activities of the urea-cycle enzymes in normal rats, although here again the fall in blood sugar concentration and the secondary consequences of this must be borne in mind. There was a tendency for the activity of liver arginase to be increased, a change significant only when expressed as total activity/100 g. body wt. This effect should be re-examined with experiments in which the blood sugar is kept high during the treatment with insulin, since this can cause considerable modification in the response to insulin in vivo; Chaikoff \& Larson (1935) have an example of this in relation to changes in uric acid concentrations.

In the group of diabetic rats treated with insulin for 2.5 days an unexpected and marked rise occurred in the activities of the enzymes of the urea cycle located in the soluble fraction of the cell, the enzymes of the arginine-synthetase system and arginase, when expressed either as total units (Fig. 7) or as total units $/ 100 \mathrm{~g}$. body wt. (Table 6 ). The units of enzyme activity/g. of liver remained unchanged in these insulin-treated diabetic animals compared with those of the diabetic group, with the exception of argininosuccinase (Table 6), and the increase was almost entirely due to the striking increase in liver weight, which almost doubled as a result of this treatment. Since, in general, insulin treatment tends to reverse the changes occurring in the diabetic animal, this experiment was repeated with longer periods (4 days) of insulin treatment (Table 6), and here the concentrations of all the urea-cycle enzymes (units/g. of liver) fell in relation to the values for diabetic rats with the exception of arginase; these changes were highly significant statistically. However, since the liver was still markedly increased in size the total hepatic contents of all the urea-cycle

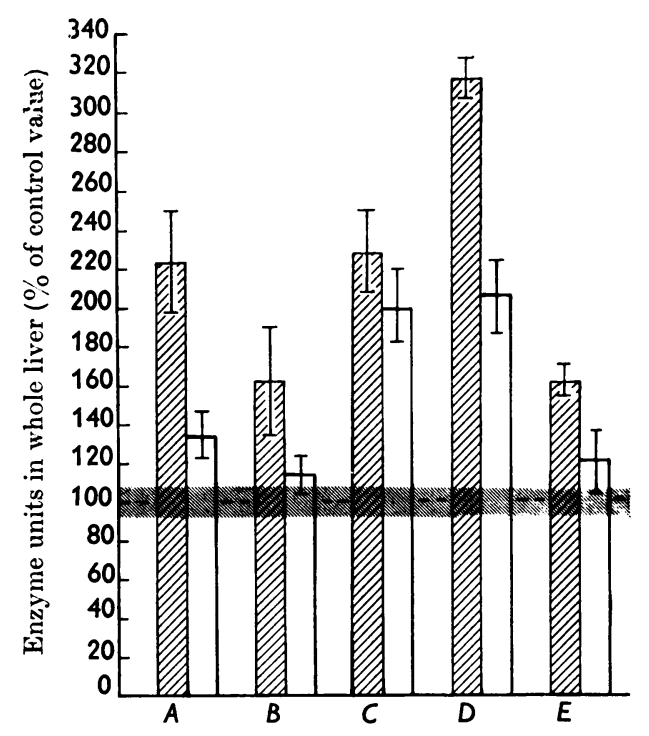

Fig. 7. Effect of different periods of insulin treatment on the activities of urea-cycle enzymes in alloxan-diabetic rats. Results, as enzyme units in the whole liver, are expressed as percentages of activity in the control normal rats. Values for alloxan-diabetic rats treated with 2 units of protamine-zinc-insulin/day for 2.5 days; $\square$, values after 4 days of treatment. A final injection of crystalline zincinsulin ( 2 units) was given $1 \mathrm{hr}$. before the animals were killed. The vertical lines represent twice the s.E.M. The horizontal broken line is the arbitrarily fixed control value of $100 \%$, the shaded area on either side of the broken line representing twice the s.E.M. for the control group. Each group contains six animals. $A$, Carbamoyl phosphate synthetase; $B$, ornithine transcarbamoylase; $C$, argininesynthetase system; $D$, argininosuccinase; $E$, arginase.

enzymes were close to the values for diabetic rats (Table 6 and Fig. 7). Clearly this period of treatment shows a turning point and the beginning of the return of the activities of the urea-cycle enzymes towards control normal values, but longer periods of treatment or higher doses of protamine-zinc-insulin would be needed to show this effect.

The composition of the livers in these groups of animals showed that the amount of RNA P and protein/g. of tissue did not alter significantly as a result of insulin treatment, although there was a slight fall in the DNA $\mathrm{P} / \mathrm{g}$. of liver. It is therefore apparent that there is a considerable increase in the total liver protein and RNA $P$ as a result of insulin treatment.

The addition of insulin ( 1 i.u. of crystalline insulin from Novo Terapeutisk) in vitro in $200 \mathrm{mg}$. batches of liver slices from normal and diabetic rats did not alter the rate of urea synthesis from added ammonia and ornithine. 


\section{DISCUSSION}

The metabolic patterns of diabetic rats and of rats treated with glucagon are characterized by a high rate of amino acid catabolism and urea output. It is not entirely surprising therefore that in these two treated groups a striking resemblance should exist in the adaptations that have occurred in the activities of the urea-cycle enzymes. In both the diabetic and glucagon-treated animals the same three enzymes (the mitochondria-linked carbamoyl phosphate synthetase and the two supernatant enzymes argininosuccinate synthetase and argininosuccinase) have increased activity, whereas the activities of the remaining mitochondrial enzyme (ornithine transcarbamoylase) and of the remaining supernatant enzyme (arginase) are completely unchanged. The present results are in agreement with those of Freedland \& Sodikoff (1962), who have also studied the activity of argininosuccinate synthetase in a variety of conditions including diabetes.

The question now arises as to how far this pattern is typical of conditions that result in high urea output. To date five conditions have been investigated in which all five urea-cycle enzymes have been measured, and Table 7 summarizes this information from a number of sources. From Table 7 it would seem that no consistent pattern can be detected for all five enzymes. However, the two enzymes comprising the arginine-synthetase system appear to vary together, with argininosuccinate activity increasing slightly more than that of argininosuccinate synthetase. This finding is consistent with the arginine-synthetase system being rate-limiting in urea formation and represents another example of control of a metabolic pathway by the activity of the rate-limiting enzyme. It is also evident from Table 7 that diabetes and glucagon treatment produce changes that are closely similar to each other but different from the changes caused by the other conditions listed. This is chiefly notable in the activity of carbamoyl phosphate synthetase, where a disproportionate increase is found in high-protein diet, starvation and cortisone treatment. Ornithinetranscarbamoylase and arginase activities, when considered in relation to the change in that of argininosuccinate synthetase, do not vary greatly in the five conditions, a finding probably best explained in terms of the high potential activities of these enzymes. Under optimum conditions these two enzymes have activities 100 -fold (for ornithine transcarbamoylase) and 1000-fold (for arginase) that of the rate-limiting enzyme. However, these optimum rates may bear little relation to activity in

Table 7. Changes in the activities of urea-cycle enzymes in some conditions that produce increased urea output

The upper part of the Table shows results from the literature on the changes in the activities of urea-cycle enzymes, under some conditions resulting in increased urea output, expressed as:

$$
\frac{\text { Total liver enzyme in treated animals }}{\text { Total liver enzyme in control animals }} \times 100
$$

The relative changes in the two mitochondria-linked enzymes, carbamoyl phosphate synthetase and ornithine transcarbamoylase, and in the two enzymes that make up the arginine-synthetase system, are shown as quotients in the lower part of the Table.

Total enzyme units in liver (\% of control value)

\section{Condition}

High-protein diet Starvation (7 days) Cortisone treatment Alloxan-diabetes Glucagon treatment

High-protein diet Starvation (7 days) Cortisone treatment Alloxan-diabetes Glucagon treatment

$\begin{array}{ccccc}\begin{array}{c}\text { Carbamoyl } \\ \text { phosphate } \\ \text { synthetase }\end{array} & \begin{array}{c}\text { Ornithine } \\ \text { trans- } \\ \text { carbamoylase }\end{array} & \begin{array}{c}\text { Arginino- } \\ \text { succinate } \\ \text { synthetase }\end{array} & \begin{array}{c}\text { Arginino- } \\ \text { succinase }\end{array} & \text { Arginase } \\ 650 & 231 & 278 & 334 & 156 \\ 503 & 422 & 347 & 492 & 201 \\ 315 & 142 & 138 & 185 & 126 \\ 158 & 109 & 170 & 203 & 117 \\ 124 & 88 & 142 & 158 & 111\end{array}$

Relative changes in total enzyme activities

\begin{tabular}{cc}
\hline Carbamoyl phosphate synthetase & Argininosuccinate synthetase \\
\cline { 1 - 2 } Ornithine transcarbamoylase & Argininosuccinase \\
2.81 & 1.20 \\
1.19 & $1 \cdot 42$ \\
2.22 & 1.34 \\
1.45 & $1 \cdot 19$ \\
1.41 & $1 \cdot 11$
\end{tabular}


vivo, particularly since the substrate concentrations are different from those used in the assay system. The activities of carbamoyl phosphate synthetase and ornithine transcarbamoylase, the two mitochondrial enzymes, do not vary together, i.e. their total activity is not simply a function of mitochondrial numbers.

The close similarity between the overall pattern of diabetic and glucagon-treated rats emphasizes the point that an alloxan-diabetic rat may, in this respect, be regarded as a glucagon-treated animal. Since insulin and glucagon have antagonistic actions, the destruction of the $\beta$-cells by alloxan treatment leaves the animal subject only to glucagon. Although the rate of glucagon secretion may be lower in a diabetic animal than in a normal, as the rate of secretion is partly governed by the blood sugar (Unger, Eisentraut, McCall \& Madison, 1962), even a small rate in the absence of insulin could exert a dramatic effect (Tyberghein, 1961). That the magnitude of the effect of treatment of normal rats with glucagon is rather less than that observed in the diabetic may be explained by the relatively short half-life of injected glucagon (Berson, Yalow, \& Volk, 1957; Cox, Henley, Narahara, Van Arsdel \& Williams, 1957), together with the antagonistic effect of insulin. This antagonistic action is well illustrated in the experiments of Miller $(1960,1961)$, in which it was shown that the protein-catabolic effect of glucagon in a perfused liver preparation could be abolished by insulin, whereas its glycogenolytic action was unimpaired.

In view of the many different results that have been published on the effect of diabetes on the concentrations of cofactors and enzymes (see de Duve \& Hers, 1957), results obtained on rats in diabetic coma are included here (Table 3). These animals show a very different pattern of enzyme change, and only argininosuccinase has an activity greater than that found in control rats, illustrating that increasing severity of the diabetic condition does not necessarily accentuate the changes found in the milder condition.

Treatment of diabetic rats with protamine-zincinsulin gives the surprising result of an increase in the activities of the three enzymes found in the cytoplasmic fraction, an increase largely due to the increased liver weight caused by this treatment. It is not until after 4 days of protamine-zinc-insulin treatment that the activities of these enzymes begin to fall. The slow response of the urea-cycle enzymes compared with the action of insulin in restoring carbohydrate and fat metabolism is in keeping with the observation of Haft \& Miller (1958), who found that the large increase in ureogenesis in perfused liver of diabetic rats was not modified by insulin, even though this treatment altered the blood sugar concentration and lipogenesis. The increase in total liver RNA $\mathrm{P}$ in diabetic rats treated with insulin (Table 6) is in keeping with the observations of Leslie \& Davidson (1951), who found that insulin caused an increase in RNA P in embryonic tissues growing in vitro, and of Wool \& Munro (1963), who found that insulin enhanced RNA synthesis in muscle.

The increase in the activities of urea-cycle enzymes with glucagon treatment and in diabetic rats treated with insulin is also of interest in relation to the work of Salter, de Meyer \& Best (1958) and Best (1959) on the inhibition of tumour growth, particularly Walker carcinoma, by combined glucagon and insulin treatment. The increase in these enzymes, important in the catabolism of amino acids, may have some bearing on their observations.

Control of metabolic pathways can be at the substrate level, as well as by changes in enzyme concentration. Of the amino acids immediately associated with the urea cycle Schimke (1963) has shown that the intracellular concentration of ornithine, citrulline and arginine remained relatively constant under a wide variety of conditions in which there are significant differences in enzyme activity and urea excretion. These results suggest control of urea-cycle activity by feedback mechanisms, a point raised by Flores, Rosado, Torres \& Soberon (1962) with respect to citrulline concentration in livers of carbon tetrachloride-treated rats. This particular amino acid might be expected to change in concentration, since the potential rate of synthesis is much greater than the rate of its removal by the rate-limiting step argininosuccinate synthetase, an enzyme that alters markedly in different physiological conditions. The work of Gornall \& Hunter (1943), showing that high concentrations of ornithine lead to an accumulation of citrulline and, in very high concentrations, cause a decrease in urea output by liver slices, is also relevant here. The complexities of the control mechanisms are also illustrated by the evidence that liver arginase is inhibited by ornithine (Edlbacher \& Zeller, 1936; Bach, Crook \& Williamson, 1944). It is, presumably, the balance of these control mechanisms that maintains the three amino acids of the urea cycle within the narrow range of concentration found by Schimke (1963).

Other amino acids closely integrated with the urea cycle are aspartic acid, which donates an amino group in the argininosuccinate-synthetase reaction, and glutamic acid, which is linked by way of glutamate dehydrogenase (see Ratner, 1954, p. 399). The direction of this latter enzyme reaction is greatly influenced by the oxidation-reduction state of the nicotinamide nucleotides. The concentration of aspartic acid in the liver falls dramatically in diabetic rats, whereas that of glutamic acid remains relatively unchanged (Kirsten, Kirsten, Hohorst \& 
Bücher, 1961). This, together with the increase in the amount of $\mathrm{NADH}$ relative to $\mathrm{NAD}^{+}$(Glock \& McLean, 1955; Hohorst, Kreutz \& Reim, 1961) (a point, incidentally, on which there is no general agreement; see also Helmreich, Holzer, Lamprecht \& Goldschmidt, 1954; Greenbaum \& Graymore, 1956), suggests that these substrate and coenzyme changes are in part a result of rather than a causative effect of the increased urea output in diabetic rats.

Of the other factors required for urea synthesis, the concentration of ATP may be lowered in the diabetic state (see Krahl, 1961). Carbon dioxide may also be deficient, as shown by Frohman \& Orten (1956), who found that the administration of bicarbonate corrected some defects in the tricarboxylic acid cycle. No information appears to be available on the concentration of $N$-acetylglutamic acid in diabetic animals, although the concentration of pyridoxal phosphate, the cofactor for transamination reactions, is unchanged in diabetes (Fasella, Baglioni, Turano \& Siliprandi, 1960). Changes in the activities of some of the enzymes associated with the urea cycle have also been reported. Transaminase activity is increased in diabetic rats (Copenhaver, Shipley \& Meyer, 1951; Rosen, Roberts, \& Nichol, 1959; Fitch \& Chaikoff, 1962) and in glucagon-treated rats (Okuno, 1960). Fitch \& Chaikoff (1962) have found an increase in fumarase activity in diabetic rats. These authors drew attention to the fact that about one-third of the amino acids found in proteins pass through fumarate during gluconeogenesis. The increased activity of this enzyme may also be of significance in relation to the equilibrium position of argininosuccinase (Ratner, Anslow \& Petrack, 1953), the action of which is to produce arginine and fumarate.

The enzyme changes shown in the present study appear to fit the metabolic pattern characteristic of diabetes. However, the time-sequence of change in relation to the insulin response suggests that the primary effect of insulin is not located in the urea cycle, the changes of which constitute only a part of the very comprehensive adaptations occurring in diabetic and glucagon-treated rats.

We are indebted to Professor F. Dickens, F.R.S., and to Dr A. L. Greenbaum for their advice and for many helpful discussions, and to Miss M. Gurney for valuable assistance. This work has been in part financed by a grant to the Medical School from the British Empire Cancer Campaign.

\section{REFERENCES}

Archibald, R. M. (1944). J. biol. Chem. 156, 121. Archibald, R. M. (1945). J. biol. Chem. 157, 507. Atchley, D. W., Loeb, R. F., Richards, D. W., Benedict, E. M. \& Driscoll, M. E. (1933). J. clin. Invest. 12, 297.
Bach, S. J., Crook, E. M. \& Williamson, S. (1944). Biochem. J. 38, 325.

Berson, S. A., Yalow, R. S. \& Volk, B. W. (1957). J. Lab. Clin. Med. 49, 331.

Best, C. H. (1959). Ciba Found. Symp.: Significant Trends in Medical Research, p. 164. Ed. by Wolstenholme, G. E. W., O'Connor, C. M. \& O'Connor, M. London: J. and A. Churchill Ltd.

Brown, G. W., jun., \& Cohen, P. P. (1959). J. biol. Chem. 234, 1769.

Burton, K. (1956). Biochem. J. 62, 315.

Chaikoff, I. L. \& Forker, L. L. (1950). Endocrinology, 46, 319.

Chaikoff, I. L. \& Larson, P. S. (1935). J. biol. Chem. 109, 85.

Claisen, L. \& Manasse, O. (1889). Ber. dtsch. chem. Ges. 22, 526.

Copenhaver, J. H., Shipley, E. G. \& Meyer, R. K. (1951). Arch. Biochem. Biophys. 34, 360.

Cox, R. W., Henley, E. D., Narahara, H. T., Van Arsdel, P. P. \& Williams, R. H. (1957). Endocrinology, 60, 277. de Duve, C. (1953). Lancet, i, 99.

de Duve, C. \& Hers, H. G. (1957). Annu. Rev. Biochem. 26, 149.

Dickens, F. \& Weil-Malherbe, H. (1943). Cancer Res. 3, 73.

Dische, Z. (1930). Mikrochemie, 8, 4.

Edlbacher, S. \& Zeller, A. (1936). Hoppe-Seyl. Z. 242, 253.

Fasella, P., Baglioni, C., Turano, C. \& Siliprandi, N. (1960). Clin. chim. Acta, 5, 146.

Fitch, W. M. \& Chaikoff, I. L. (1962). Biochim. biophys. Acta, 57, 588.

Flores, G., Rosado, A., Torres, J. \& Soberon, G. (1962). Amer. J. Physiol. 203, 43.

Folley, S. J. \& Greenbaum, A. L. (1948). Biochem. J. 43, 537.

Folley, S. J. \& Greenbaum, A. L. (1949). J. Endocrin. 6, x. Freedland, R. A. \& Sodikoff, C. H. (1962). Proc. Soc. exp. Biol., N.Y., 109, 394.

Frohman, C. E. \& Orten, J. M. (1956). J. biol. Chem. 220, 315.

Glock, G. E. \& McLean, P. (1955). Biochem.J. 61, 397.

Gornall, A. G. \& Hunter, A. (1943). J. biol. Chem. 147, 593.

Greenbaum, A. L. \& Graymore, C. N. (1956). Biochem. J. 63, 163.

Haft, D. E. \& Miller, L. L. (1958). Amer. J. Physiol. 192, 33.

Helmreich, E., Holzer, H., Lamprecht, W. \& Goldschmidt, W. (1954). Hoppe-Seyl. Z. 297, 113.

Hohorst, H. J., Kreutz, F. H. \& Reim, M. (1961). Biochem. biophys. Res. Commun. 4, 163.

Kass, E. H. \& Waisbren, B. A. (1945). Proc. Soc. exp. Biol. N.Y., 60, 303.

Kirsten, E., Kirsten, R., Hohorst, H. J. \& Bücher, Th. (1961). Biochem. biophys. Res. Commun. 4, 169.

Klebanoff, S. J. \& Greenbaum, A. L. (1954). J. Endocrin. 11, 314.

Krahl, M. E. (1961). The Action of Insulin on Cells. p. 59. New York and London: Academic Press Inc.

Krebs, H. A. (1952). In The Enzymes, vol. 2, part 2, p. 866. Ed. by Sumner, J. B. \& Myrbäck, K. New York: Academic Press Inc.

Krebs, H. A. \& Henseleit, K. (1932). Hoppe-Seyl. Z. 210, 33.

Leslie, I. \& Davidson, J. N. (1951). Biochem.J. 49, xli. 
Lowry, O.H., Rosebrough, N.J., Farr, A. L. \& Randall, R.J. (1951). J. biol. Chem. 193, 265.

Lukens, F. D. W. (1959). Annu. Rev. Physiol. 21, 445.

McLean, P. \& Gurney, M. W. (1963). Biochem. J. 87, 96.

McLean, P., Novello, F.\& Gurney, M. W. (1965). Biochem.J. 94, 422 .

Mejbaum, W. (1939). Hoppe-Seyl. Z. 258, 117.

Miller, L. L. (1960). Nature, Lond. 185, 248.

Miller, L. L. (1961). Recent Prog. Hormone Res. 17, 539.

Minkowski, O. (1893). Arch. exp. Path. Pharmakol. 31, 85.

Nelson, N. (1944). J. biol. Chem. 153, 375.

Okuno, G. (1960). Med.J. Osaka Univ. 10, 483.

Randle, P. J. (1963). Annu. Rev. Physiol. 25, 291.

Ratner, S. (1954). Advanc. Enzymol. 21, 199.

Ratner, S., Anslow, W. P., jun., \& Petrack, B. (1953). J. biol. Chem. 204, 115.

Rosen, F., Roberts, N. R. \& Nichol, C. A. (1959). J. biol. Chem. 234, 476.

Salter, J. M., Davidson, I. W. F. \& Best, C. H. (1957). Diabetes, 86, 248.
Salter, J. M., de Meyer, R. \& Best, C. H. (1958). Brit. med.J. ii, 5.

Schimke, R. T. (1962a). J. biol. Chem. 237, 459.

Schimke, R. T. (1962b). J. biol. Chem. 237, 1921.

Schimke, R. T. (1963). J. biol. Chem. 238, 1012.

Schneider, W. C. (1946). J. biol. Chem. 164, 747.

Soskin, S. \& Levine, R. (1946). Carbohydrate Metabolism, p. 105. University of Chicago Press.

Spector, L., Jones, M. E. \& Lipmann, F. (1957). In Methods in Enzymology, vol. 3, p. 653. Ed. by Colowick, S. P. \& Kaplan, N. O. New York: Academic Press Inc.

Tyberghein, J. M. (1953). Arch. int. Physiol. 61, 104.

Tyberghein, J. M. (1961). Endocrinology, 69, 312.

Umbreit, W. W., Burris, R. H. \& Stauffer, J. F. (1949). Manometric Techniques and Tissue Metabolism, 2nd ed., p. 119. Minneapolis: Burgess Publishing Co.

Unger, R. H., Eisentraut, A. M., McCall, M. S. \& Madison, L. L. (1962). J. clin. Invest. 41, 682.

Wool, I. G. \& Munro, A. J. (1963). Proc. nat. Acad. Sci., Wash., 50, 918.

Biochem.J. (1965) 94, 422

ADDENDUM

\title{
Some Observations on the Colorimetric Determination of Citrulline and Urea
}

\author{
By PATRICIA MCLEAN, F. NOVELLO* AND MARY W. GURNEY \\ Courtauld Institute of Biochemistry, The Middlesex Hospital Medical School, London, W. 1
}

(Received 8 May 1964)

In a study of some control mechanisms of ureacycle enzymes it was observed that the addition of urea appeared to potentiate the activity of carbamoyl phosphate synthetase (adenosine triphosphate-carbamate phosphotransferase; EC 2.7.2.1). Since this enzyme is measured by the amount of citrulline formed and both citrulline and urea react with diacetylmonoxime (Archibald, 1944), an investigation of the possible interaction of citrulline and urea in this diacetylmonoxime reaction was undertaken. The work of Fearon (1939) and Gornall \& Hunter (1941) had already indicated the possibility of interactions of the type described below. Gornall \& Hunter (1941) in fact found that tissue filtrates contained material that increased the colour reaction of citrulline in the diacetylmonoxime reaction of Fearon (1939), and they removed the

* Present address: Institute of General Pathology, University of Padua, Italy. interfering material with urease. In the present study it was found that when urea and citrulline were present together the resultant colour formed with diacetylmonoxime was greater than the sum of the two compounds measured independently. In conditions where high amounts of urea are present, as, for example, in preparations from alloxandiabetic rat livers, this interference may assume considerable importance in the assay of the two urea-cycle enzymes that are measured by the amount of citrulline formed, i.e. carbamoyl phosphate synthetase and ornithine transcarbamoylase (carbamoyl phosphate-L-ornithine carbamoyltransferase, EC 2.1.3.3.)

The present work reports the interaction of citrulline with urea and with a number of substituted ureas in the colour reaction with diacetylmonoxime described by Archibald (1944), and gives a method for correcting for this interference. 


\section{METHODS}

Materials. Commerical reagents were used with the exception of $\alpha$-isonitrosopropiophenone, which was synthesized by the method of Claisen \& Manasse (1889), and carbamoylglycine, which was a gift from Dr Margaret Foulkes, Westminster Hospital, London. Carbamoylaspartate and carbamoylglutamate were obtained from Sigma Chemical Co., St Louis, Mo., U.S.A.

Diacetylmonoxime reaction. The diacetylmonoxime reaction for citrulline described by Archibald (1944) was used, the only modification being that the heating time was extended from 10 to $15 \mathrm{~min}$. to obtain more reproducible results. Precautions were taken to exclude light during colour development. Citrulline and urea, or substituted ureas, were heated singly and in combination together with diacetylmonoxime, and the absorption and difference spectra were determined. The values reported in Table 1 and Figs. 3 and 4 are for $E_{490 \mathrm{~m} \mu}^{1 \mathrm{~cm}}$, the absorption maximum for the colour developed with citrulline. A Hilger Uvispek spectrophotometer was used.

$\alpha$-Isonitrosopropiophenone reaction. The colour reaction with $\alpha$-isonitrosopropiophenone (Archibald, 1945) was used for determining urea.

\section{RESULTS AND DISCUSSION}

Archibald (1944) has shown that both citrulline and urea react with diacetylmonoxime to give coloured products, the former with a maximum absorption at $490 \mathrm{~m} \mu$ and the latter at $480 \mathrm{~m} \mu$. In the present experiments it was found that when urea and citrulline were present together the resultant colour formed with diacetylmonoxime was greater than the sum of the two compounds measured independently, i.e. there is a potentiating effect. The results of these experiments are shown in Figs. 1-4.

The absorption spectrum for $60 \mu \mathrm{g}$. of citrulline heated for $15 \mathrm{~min}$. at $100^{\circ}$ with diacetylmonoxime and the difference spectrum for $60 \mu \mathrm{g}$. of citrulline when treated in some way with the addition of $60 \mu \mathrm{g}$. of urea are shown in Fig. 1. This difference spectrum is obtained from the data in Fig. 2, which shows the absorption spectra for $60 \mu \mathrm{g}$. of citrulline plus $60 \mu \mathrm{g}$. of urea and for $60 \mu \mathrm{g}$. of urea alone. In accordance with the values given by Archibald (1944), the absorption maximum for citrulline alone is at $490 \mathrm{~m} \mu$; however, the difference spectrum has a maximum at $485 \mathrm{~m} \mu$. The considerable increase in extinction at $490 \mathrm{~m} \mu$ between citrulline alone and citrulline measured by this difference spectrum can be clearly seen and illustrates the potentiating effect of urea on the reaction.

Effect of urea on citrulline calibration curve. The potentiating effect of different concentrations of urea on the colour reaction of one concentration of citrulline with diacetylmonoxime was measured and the results of these experiments are shown in Fig. 3. 'This shows the reaction of urea, urea plus citrulline

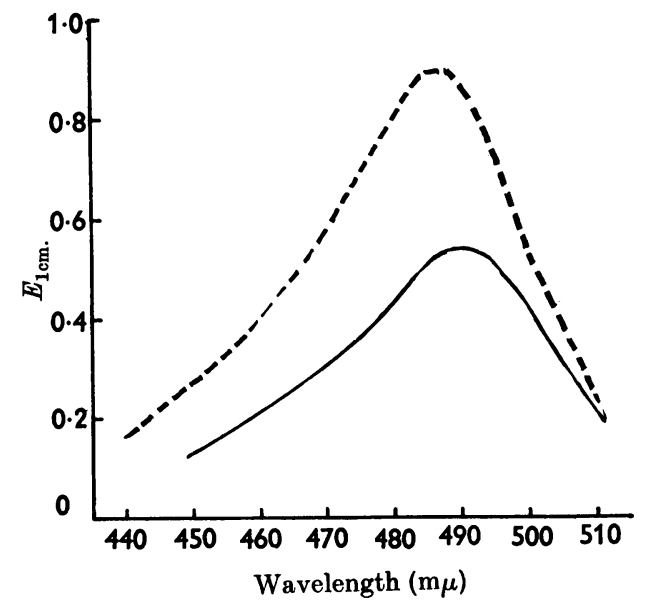

Fig. 1. Reaction of citrulline with diacetylmonoxime in the presence and absence of urea. - $\longrightarrow$ Absorption spectrum for $60 \mu \mathrm{g}$. of citrulline heated for $15 \mathrm{~min}$. at $100^{\circ}$ with diacetylmonoxime; ........, difference spectrum for $60 \mu \mathrm{g}$. of citrulline when treated in the same way with the addition of $60 \mu \mathrm{g}$. of urea. The difference spectrum is obtained from data shown in Fig. 2.

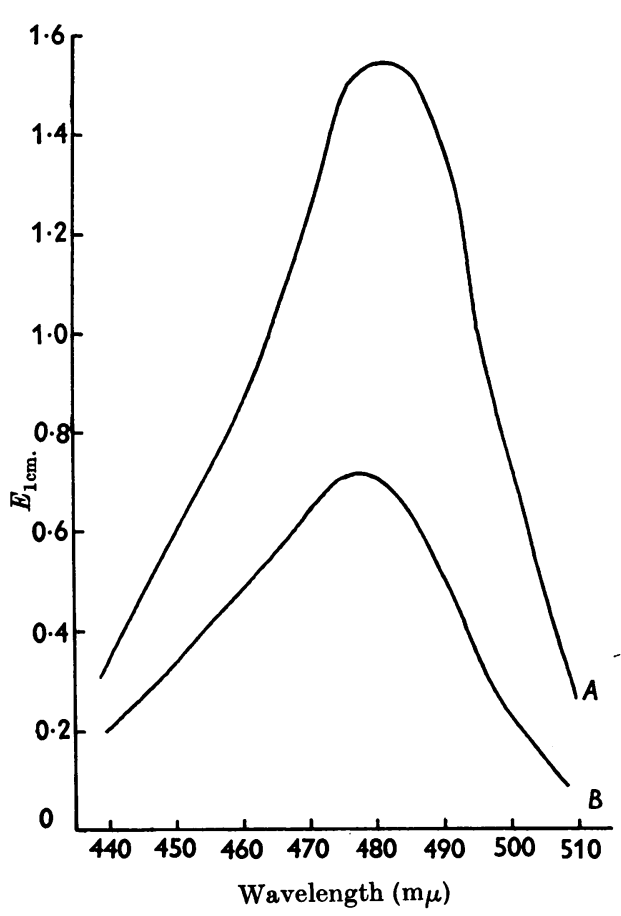

Fig. 2. Reaction of urea and citrulline with diacetylmonoxime. $A$, Absorption spectra for citrulline (60 $\mu \mathrm{g}$.) + urea $(60 \mu \mathrm{g}$.); $B$, absorption spectra for urea $(60 \mu \mathrm{g}$.) alone. The difference between these two is shown by the citrulline difference spectra in Fig. 1 . The colour reaction of Archibald (1944) was used; the time of heating was $15 \mathrm{~min}$. and the colours were read $10 \mathrm{~min}$. later. 


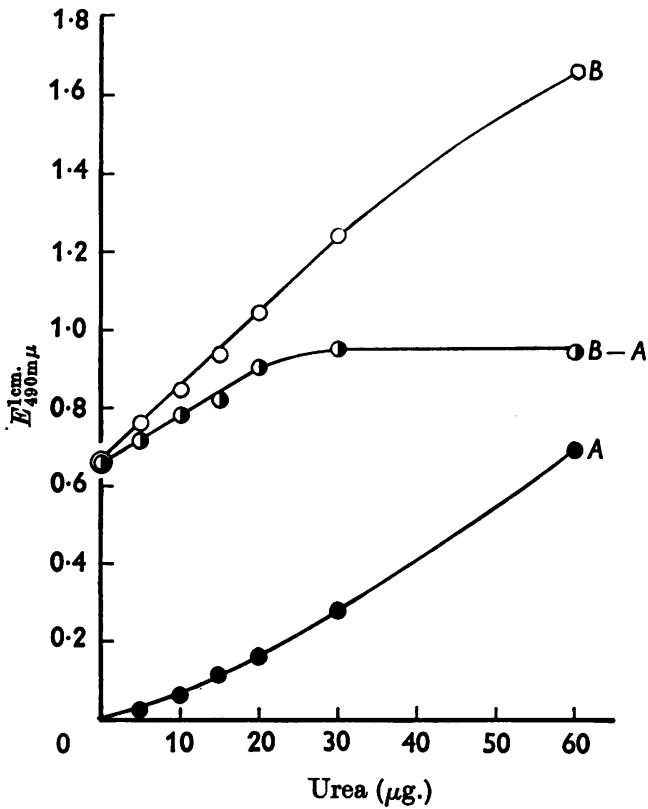

Fig. 3. Effect of urea in potentiating the colour of citrulline with diacetylmonoxime. The diacetylmonoxime reaction (Archibald, 1944) was used, the time of heating was $15 \mathrm{~min}$. and the colours were read $10 \mathrm{~min}$. later at $490 \mathrm{~m} \mu$. The curves represent: 0 , urea alone $(0-60 \mu \mathrm{g}$.) $(A)$; $O$, urea $(0-60 \mu \mathrm{g}$.$) together with citrulline ( 70 \mu \mathrm{g}$.) $(B)$; 0 , citrulline (70 $\mu \mathrm{g}$.$) and the effect of different concentrations of urea in$ potentiating the colour reaction with diacetylmonoxime $(B-A)$.

and, by difference, citrulline with diacetylmonoxime. The citrulline content was kept constant $(60 \mu \mathrm{g}$.) and that of urea was varied from 0 to $60 \mu \mathrm{g}$. The curve obtained by difference shows that urea potentiates the colour reaction of citrulline. The potentiating effect is marked at low urea contents (5 $\mu \mathrm{g}$.$) , and urea has an increasing effect up to a$ content of $30 \mu \mathrm{g}$.; thereafter the addition of further urea produced no further enhancement of colour as measured by the difference spectrum. The numerical values for certain of these points are given in Table 1.

The results in Fig. 4 show the normal citrulline calibration curve (range 30-90 $\mu \mathrm{g}$. of citrulline), with the characteristic non-linearity of the lower values, an effect probably due to the unstable nature of the coloured product in light (Archibald, 1944), together with the same amounts of citrulline heated with diacetylmonoxime in the presence of urea $(15-60 \mu \mathrm{g}$.$) . The latter calibration curves are$ calculated by difference (from citrulline plus urea together and urea alone). Fig. 4 shows that the effect of urea is greatest at low concentrations of

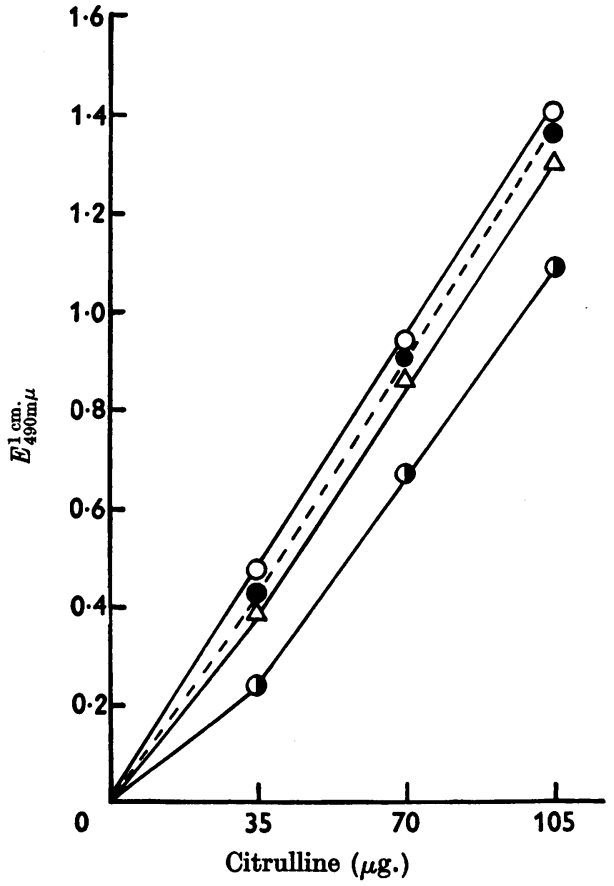

Fig. 4. Alterations in the citrulline calibration curve due to the potentiating effect of urea. The diacetylmonoxime reaction (Archibald, 1944) was used; the time of heating was $15 \mathrm{~min}$. and the colours were read $10 \mathrm{~min}$. later at $490 \mathrm{~m} \mu$. The curves represent: $O$, colour due to citrulline (35-105 $\mu$ g.) alone; $\Delta$, colour due to [citrulline (35-105 $\mu \mathrm{g}$.) + urea (15 $\mu \mathrm{g}$.)] - colour due to urea (15 $\mu \mathrm{g}$.); $\bullet$, colour due to [citrulline (35-105 $\mu \mathrm{g}$.) + urea $(30 \mu \mathrm{g}$.$) ] - colour due to$ urea $(30 \mu \mathrm{g}$.$) ; \bigcirc$, colour due to [citrulline (35-105 $\mu \mathrm{g}$.) + urea $(60 \mu \mathrm{g})$.$] - colour due to urea (60 \mu \mathrm{g}$.)

citrulline. This effect is reproducible provided that the time of heating is carefully controlled.

Correction as applied to carbamoyl phosphatesynthetase assay. In extracts where appreciable amounts of urea are present, as in livers from alloxan diabetic rats, the urea content of the tissue alone must be determined separately, for example by the sensitive colorimetric method with $\alpha$-isonitrosopropiophenone described by Archibald (1945). The citrulline calibration curve is then determined in the presence of the appropriate amount of urea, and this curve used in the calculation of the activity of carbamoyl phosphate synthetase. The amount of enzyme used for the assay of ornithine transcarbamoylase is so small $(0.01 \mathrm{ml}$. of supernatant fraction from a 1:10 liver homogenate prepared in 0.1\% cetyltrimethylammonium bromide) that no such correction is necessary for this enzyme.

The magnitude of the correction factor may be judged by the fact that the value for the $30 \mu \mathrm{g}$. of 


\section{Table 1. Effect of urea and some substituted ureas on the colour} reaction of citrulline and diacetylmonoxime

The colour reaction of Archibald (1944) was used; the time of heating was $15 \mathrm{~min}$. and the colour read $10 \mathrm{~min}$. later. The reaction tubes were protected from light throughout. The absorption maxima were as follows: citrulline, $490 \mathrm{~m} \mu$; urea, $480 \mathrm{~m} \mu$; methylurea and ethylurea, $485 \mathrm{~m} \mu$; phenylurea, $495 \mathrm{~m} \mu$; carbamoylglycine, $490 \mathrm{~m} \mu$.

\begin{tabular}{|c|c|c|c|c|}
\hline & & & $E_{490 \mathrm{~m} \mu}^{1 \mathrm{~cm}}$ & \\
\hline & $\begin{array}{c}\text { Amount } \\
\text { added } \\
(\mu \mathrm{g} .)\end{array}$ & $\begin{array}{l}\text { Additional } \\
\text { compound }\end{array}$ & $\begin{array}{l}\text { Citrulline } \\
(60 \mu \mathrm{g} .)+ \\
\text { additional } \\
\text { compound }\end{array}$ & $\begin{array}{l}\text { Citrulline } \\
(60 \mu g .) \text { by } \\
\text { difference }\end{array}$ \\
\hline None & - & - & - & 0.555 \\
\hline Urea & 30 & 0.237 & $1 \cdot 049$ & 0.812 \\
\hline $\mathrm{H}_{2} \mathrm{~N} \cdot \mathrm{CO} \cdot \mathrm{NH}_{2}$ & 60 & 0.503 & $1 \cdot 384$ & 0.881 \\
\hline $\begin{array}{l}\text { Methylurea } \\
\mathrm{H}_{2} \mathrm{~N} \cdot \mathrm{CO} \cdot \mathrm{NH} \cdot \mathrm{CH}_{3}\end{array}$ & 30 & 0.865 & $1 \cdot 741$ & 0.876 \\
\hline Ethylurea & $\mathbf{3 0}$ & 0.716 & $1 \cdot 425$ & $0 \cdot 709$ \\
\hline $\mathrm{H}_{2} \mathrm{~N} \cdot \mathrm{CO} \cdot \mathrm{NH} \cdot \mathrm{C}_{2} \mathrm{H}_{5}$ & 60 & $1 \cdot 630$ & $2 \cdot 480$ & $0 \cdot 850$ \\
\hline $\begin{array}{l}\text { Phenylurea } \\
\mathrm{H}_{2} \mathrm{~N} \cdot \mathrm{CO} \cdot \mathrm{NH} \cdot \mathrm{C}_{6} \mathrm{H}_{5}\end{array}$ & 60 & 0.303 & $1 \cdot 083$ & 0.780 \\
\hline Carbamoylglycine & 60 & $0 \cdot 125$ & 0.839 & $0 \cdot 714$ \\
\hline $\mathrm{H}_{2} \mathrm{~N} \cdot \mathrm{CO} \cdot \mathrm{NH} \cdot \mathrm{CH}_{2} \cdot \mathrm{CO}_{2} \mathrm{H}$ & 120 & 0.370 & $1 \cdot 170$ & 0.800 \\
\hline $\begin{array}{l}\text { Carbamoylaspartic acid } \\
\mathrm{H}_{2} \mathrm{~N} \cdot \mathrm{CO} \cdot \mathrm{NH} \cdot \mathrm{CH}\left(\mathrm{CO}_{2} \mathrm{H}\right) \cdot \mathrm{CH}_{2} \cdot \mathrm{CO}_{2} \mathrm{H}\end{array}$ & 60 & 0.006 & $\mathbf{0 . 5 7 8}$ & 0.572 \\
\hline $\begin{array}{l}\text { Carbamoylglutamic acid } \\
\mathrm{H}_{2} \mathrm{~N} \cdot \mathrm{CO} \cdot \mathrm{NH} \cdot \mathrm{CH}\left(\mathrm{CO}_{2} \mathrm{H}\right) \cdot\left[\mathrm{CH}_{2}\right]_{2} \cdot \mathrm{CO}_{2} \mathrm{H}\end{array}$ & 60 & 0.001 & 0.554 & 0.553 \\
\hline $\begin{array}{l}\text { Allantoin } \\
\mathrm{H}_{2} \mathrm{~N} \cdot \mathrm{CO} \cdot \mathrm{NH} \cdot \mathrm{CH} \cdot \mathrm{CO} \cdot \mathrm{NH} \cdot \mathrm{CO} \cdot \mathrm{NH}\end{array}$ & 60 & 0.018 & 0.573 & 0.555 \\
\hline $\begin{array}{l}\text { Arginine } \\
\qquad \mathrm{H}_{2} \mathrm{~N} \cdot \mathrm{C}(: \mathrm{NH}) \cdot \mathrm{NH} \cdot\left[\mathrm{CH}_{2}\right]_{3} \cdot \mathrm{CH}\left(\mathrm{NH}_{2}\right) \cdot \mathrm{CO}_{2} \mathrm{H}\end{array}$ & 60 & 0.004 & 0.575 & 0.571 \\
\hline
\end{tabular}

citrulline standard is almost doubled by the potentiating effect of $15 \mu \mathrm{g}$. of urea (Fig. 4), and the observation that the quantity of citrulline normally formed in the assay for carbamoyl phosphate synthetase falls between the 30 and $60 \mu \mathrm{g}$. of citrulline standards. The urea content of liver extracts from alloxan-diabetic rats frequently contained quantities of urea, equivalent to 10-15 $\mu \mathrm{g}$. of urea, in the amount of enzyme added to the assay system $(0.1 \mathrm{ml}$. of supernatant from a 1:10 liver homogenate prepared in $0.1 \%$ cetyltrimethylammonium bromide).

Effect of substituted ureas. The effect of certain substituted ureas on the colour reaction of citrulline with diacetylmonoxime is given in Table 1. These compounds divide sharply into two groups: those substituted ureas that give a coloured product with diacetylmonoxime and also potentiate the colour with citrulline (see last column of Table 1), and those with neither of these properties. Gornall \& Hunter (1941) have also observed interfering effects of urea and citrulline, and have shown that both methylurea and phenylurea yield colours with the diacetylmonoxime reagent that are very similar to that obtained with citrulline. The present results show that the absorption maxima for these compounds are close to those for urea and citrulline, and are 485 and $495 \mathrm{~m} \mu$ for methylurea and phenylurea respectively. Archibald (1944) has reported that allantoin reacts with diacetylmonoxime to give a coloured product, but with the concentrations used in the present work very little colour was produced.

The carbamoyl derivatives of amino acids are of interest in this context, and in particular carbamoylaspartic acid, which is one of the first products in the pathway of pyrimidine formation. There is an inverse relationship between the activity of ornithine transcarbamoylase and aspartate transcarbamoylase in certain conditions where rapid growth is taking place and there is a high requirement for pyrimidine for DNA and RNA synthesis (see Cohen \& Sallach, 1961). However, carbamoylaspartic acid does not cause any interference in the citrulline colour reaction, an observation in keeping with the work of Koritz \& Cohen (1954) and Gerhart $\&$ Pardee (1962), who have made modifications of the diacetylmonoxime reaction to estimate this particular compound.

Of the other carbamoyl derivatives of amino acids 
tested only carbamoylglycine gave a positive reaction with diacetylmonoxime and potentiated the colour with citrulline; carbamoylglutamic acid did not have either of these properties. There is not yet sufficient information to enable speculation on the structure of compounds reacting in this way with citrulline and diacetylmonoxime beyond the generalizations given by Fearon (1939), although the difference between carbamoylglycine and carbamoylaspartic acid perhaps suggests that ring-closure in acid solution with the latter compound might account for the lack of reaction.

We are indebted to Professor F. Dickens, F.R.S., and to Dr A. L. Greenbaum for their interest and advice, and to Mr K. Greenslade for skilled technical assistance. This work has been in part financed by a grant to the Medical School from the British Empire Cancer Campaign.

\section{REFERENCES}

Archibald, R. M. (1944). J. biol. Chem. 156, 121.

Archibald, R. M. (1945). J. biol. Chem. 157, 507.

Claisen, L. \& Manasse, O. (1889). Ber. dtsch. chem. Ges. 22, 526.

Cohen, P. P. \& Sallach, H. J. (1961). In Metabolic Pathways, vol. 2, p. 1. Ed. by Greenberg, D.M. New York : Academic Press Inc.

Fearon, W. R. (1939). Biochem.J. 33, 902.

Gerhart, J. C. \& Pardee, A. B. (1962). J. biol. Chem. 237, 891.

Gornall, A. G. \& Hunter, A. (1941). Biochem. J. 35, 650.

Koritz, S. B. \& Cohen, P. P. (1954). J. biol. Chem. 209, 145. 